\title{
The research of the railway rail for analysis of surface initiated rolling contact fatigue cracks
}

\author{
Yurii Borodii ${ }^{1} \bullet$ Pavlo Protsenko $^{1} \bullet$ Andrii Petryshyn ${ }^{1} \bullet$ Eckart Uhlmann ${ }^{2} \bullet$ Janis Thalau $^{2} \bullet$ \\ Pavlo Lypovka $^{2} \bullet$ Volodymyr Horbyk ${ }^{3} \bullet$ Viktor Hlukhovskyi $^{3}$ \\ 1 - Igor Sikorsky Kyiv Polytechnic Institute, Kyiv, Ukraine; \\ 2 - Chair of Machine Tools and Manufacturing Technology, Institute for Machine Tools and Factory Management (IWF), \\ Technische Universität Berlin, Berlin, Germany; \\ 3 - Institute of electric welding them. E.O. Paton, Kyiv, Ukraine
}

Received: 27 December 2019 / Accepted: 24 February 2020

\begin{abstract}
Problems. Under the influence of dynamic loading from trains and natural conditions, the railway track deteriorates, which is characterized by defects (warps, subsidence, shocks and other residual deformations of the railway track), which lead to intense wear and collapse of all elements of the rail track panel. Listed defects precipitation, failures and destructions of elements of the rail track panel is related with additional local stresses that occur in the railway track rails. On a low-quality rail track panel with high parameters deviations, during the train movement, there is an unaccounted interaction of the track and rolling stock with local overload of the interaction elements along the path. Usually, the unaccounted interaction of track and rolling stock is accompanied by the wheel and rail impact with followed contact area overloading. During the wheel and rail impact, stresses that exceed the ultimate strength are occurring in the rail head. In this case, defects of contact-fatigue origin in the form of horizontal, vertical and transverse cracks are born and start to develop.

The aim of the study. Conducting practical studies of the contact-fatigue cracks origin and development by studying rails wear in the laboratory.

Methods of implementation. For research of rails for contact damage experimental setup has been designed and manufactured. The setup is mounted on a mechanical single-cylinder press of the $K 2322$ model with a nominal force of 16 tons at a nominal stroke frequency of 120 per minute. The main part of the experimental setup contains the friction unit "rail-wheel". The hydraulic system provides needed clamping force of the rail to the wheel. A test program, which provides for two-hour tests, followed by defects (micro cracks) detecting on the rail body has been developed. Research on the defects presence is carried out by fluorescent magnetic particle inspection method.

Research results. Studies have shown that contact-fatigue cracks in the rail head occurred after approximately 200 thousand load cycles. This generally coincides with the results presented in other works, which show the occurrence of similar damage after 190290 thousand cycles, depending on the properties of rail steel (hardness, surface roughness, etc.).

Conclusions. The main reason for the origin and development of contact-fatigue defects in the rail head is the insufficient contactfatigue strength of rail steel. For carrying out practical research in the laboratory, the experimental setup has been designed and manufactured. The test program has been developed. Experimental studies have shown that the occurrence of defects on the surface of the rail observed after 200-210 thousand load cycles. With further increase in the number of load cycles, there is a rapid development of existing contact-fatigue cracks and the formation of new cracks in the contact zone.
\end{abstract}

Keywords: rails and wheels of railway transport, rails wear of railway track, contact damage, defects of rails, contact-fatigue cracks, fluorescent magnetic particle inspection method.

Introduction. In most of the countries railway is the foundation of the transport system, which deals with 50 percent or more of passenger and freight flow.

To ensure the cargo and passengers transportation with necessary reliability and safety, the railway track must always be in good working condition, it also must have the necessary stability, reliability and low operating costs.

Under the influence of dynamic loading from trains and natural conditions, the railway track deteriorates. Rail wear intensity depends on many factors. Rail wear rate is affected by: acting load (wheel contact pressure on rail), temperature (contact), locomotive's type and mode of motion, impact from the environment, physicochemical modification of surfaces during friction and wear, lubricating properties materials and lubrication methods [1].

Often there are defects of contact-fatigue origin in the form of horizontal, vertical and transverse cracks are born and start to develop. Part of such defects with contact-fatigue origin reaches $70 \%$ of total number of rails defects [1].

The development of surface cracks with subsequent peeling of particles of the material is one of the main mechanisms of wear of the rail head during contact interaction with the wheels of the rolling stock [2].

Yurii Borodii

borodiyyuriy@ukr.net
Pavlo Protsenko

pavloprocenko64@gmail.com
Eckart Uhlmann

Thalau@iwf.tu-berlin.de 
It is known [3] that a rail in rolling contact is subjected to repeated applications of high friction loads (due to traction, braking, curving, etc.), the surface material will deform plastically. Cracks will form when the fracture strain is exceeded. This fracture strain is far above that of tensile tests, the reason being the beneficial influence of the compressive stresses [4]. In the case of alternating directions of frictional loading (for instance due to alternating traction/braking), the material will not ratchet in the same manner since plastic deformations will occur in both directions causing the accumulated plastic strain to be close to zero. Failure will be caused by low-cycle fatigue.

On straight sections of the track, such cracks most often form in the central part of the head of each rail, on curved ones - on the lateral working face of the head of the external rail [2].

Papers [5-6], devoted to this problem, notes that the main cause of contact-fatigue defects appearing and development in the rail head occur due to insufficient contact-fatigue strength of the rail steel. After multiple repeated alternating plastic deformation of the surface layers of the rail head, the plastic properties of the material are exhausted and cracks appear [2]. Thus, studies conducted in this paper are relevant and can be used to investigate the process of rail contact-fatigue defects to increase the rails and railway track life.

The aim of the work is to carry out practical studies of the contact-fatigue cracks origin and development by studying rails wear in the laboratory.

Tasks performed in the work:

- Analysis of relevance and current state of research of the problem wear and durability of rail railway tracks.

- Development of method and creation of an experimental setup for practical studies of contact damage to rails railway track.

- Conducting studies of the resistance of the rail to cracking from the influence of the wheel load.

- Development of general recommendations for studies of surface initiated rolling contact fatigue cracks of railway rails.

Core material and results. For research of rails for contact damage, the experimental setup has been designed and manufactured. Experimental setup 3D model is shown in Fig. 1. The experimental setup contains the following main parts: the running head, which is shown in fig. 2; hydraulic system, the scheme of which is shown in Fig. 3; table with different guides and fixing plates (Fig. 1). The setup is mounted on a mechanical single-cylinder press of the $\mathrm{K}$ 2322 model with a nominal force of 16 tons at a nominal stroke frequency of 120 per minute. The running head is fixed to the slide of the press KD 2322. Fig. 4 presents a general view of the experimental setup that mounted on press of the K 2322 model. Fig. 5 shows a "rail-wheel" friction unit. Fig. 6 presents a general view of the hydraulic system that provides clamping force of the rail to the wheel.

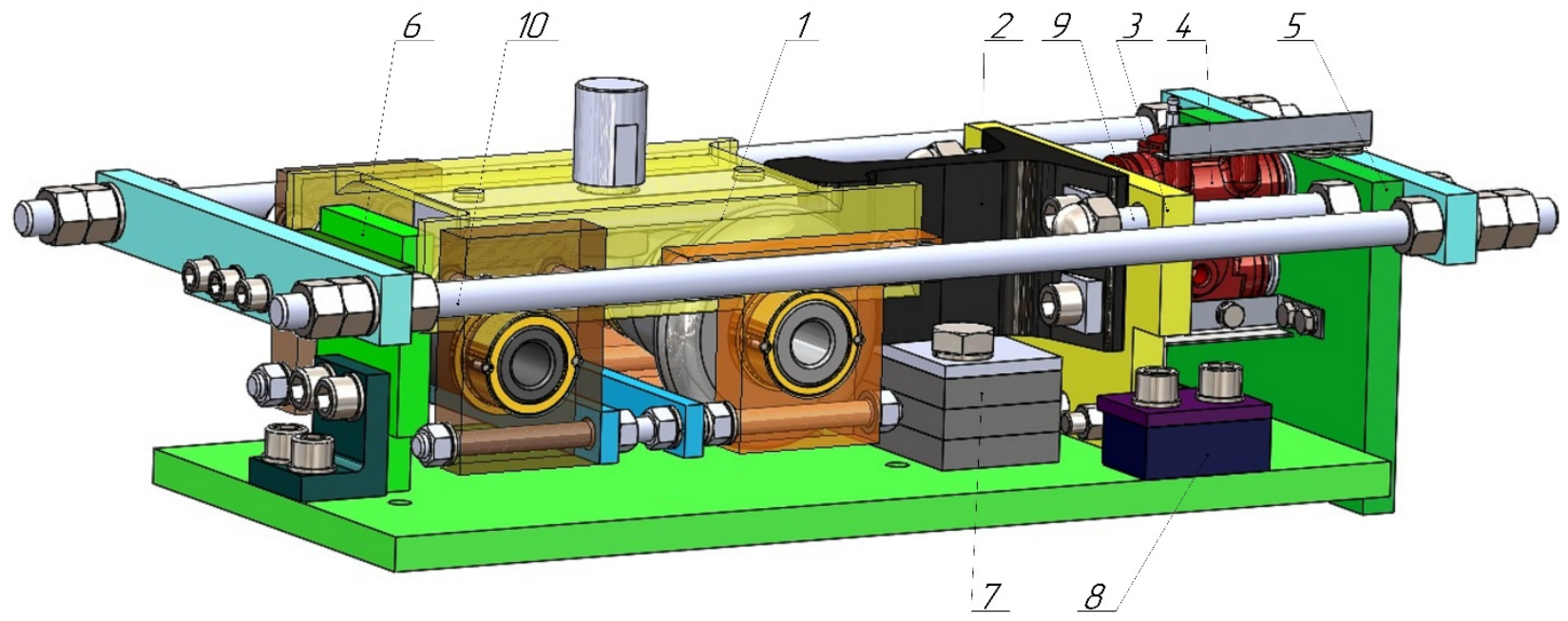

Fig. 1. Experimental setup 3D model: 1 - running head; 2 - rail; 3 - movable plate; 4 - hydraulic system; 5 - fixed plate; 6 - guide roll; 7 - set of base plates for the rail; 8 - guide for the movable plate 3 ;

9 - guide axis for the movable plate $3 ; 10$ - stud-bolt for greater rigidity setup

It is known that the local contact stresses at the contact place is calculated using the following dependence [7]:

$$
\sigma_{\text {cont }}=m \sqrt[3]{\frac{F_{w} E_{e q v}^{2}}{R_{\max }^{2}}},
$$


where $R_{\max }$ is the greater of the two radiuses ( $R_{w}$ is the wheel radius or $R_{1}$ is the radius of the rail head) of the two surfaces in contact; $\mathrm{m}$ is the coefficient depending on the ratio $R_{w} / R_{1} ; E_{\text {eqv }}$ is the equivalent modulus of elasticity of the contact surfaces wheel and rail; $F_{w}$ is the load on the wheel.

Since in the setup must have the same conditions of the shaft-wheel and rail contact as the actual contact of the train wheel with the rail, then the force to be generated by the hydraulic system can be determined from the following expression:

$$
F_{w}^{\text {setup }}=\frac{m_{\text {train }}^{3} \cdot F_{\mathrm{w}}^{\text {train }} \cdot\left(E_{\text {eqv }}^{\text {train }}\right)^{2} \cdot\left(R_{\text {max }}^{\text {setup }}\right)^{2}}{m_{\text {setup }}^{3} \cdot\left(E_{\text {eqv }}^{\text {setup }}\right)^{2} \cdot\left(R_{\max }^{\text {train }}\right)^{2}}
$$

where $R_{\max }^{\text {train }}$ is the greater of two radiuses (wheel or rail head) of two contact surfaces in real contact a rail with a train wheel; $R_{\max }^{\text {setup }}$ is the greater of two radiuses (shaft-wheel or rail head) of two contact surfaces in the setup; $m_{\text {train }}$ is coefficient that depends on the ratio of radiuses of the contact surfaces (wheel and rail head) in the real contact the train wheel and the rail; $m_{\text {setup }}$ is coefficient that depends on the ratio of radiuses of contact surfaces (shaft-wheel and rail head) in the setup; $E_{\text {eqv }}^{\text {train }}$ is equivalent module of elasticity of contact surfaces (wheel and rail) in the real contact the train wheel and the rail; $E_{\text {eqv }}^{\text {setup }}$ is equivalent modulus of elasticity of contact surfaces (shaft-wheel and rail) in the setup; $F_{\mathrm{w}}^{\text {train }}$ is the load transmitted from the train wheel to the rail.

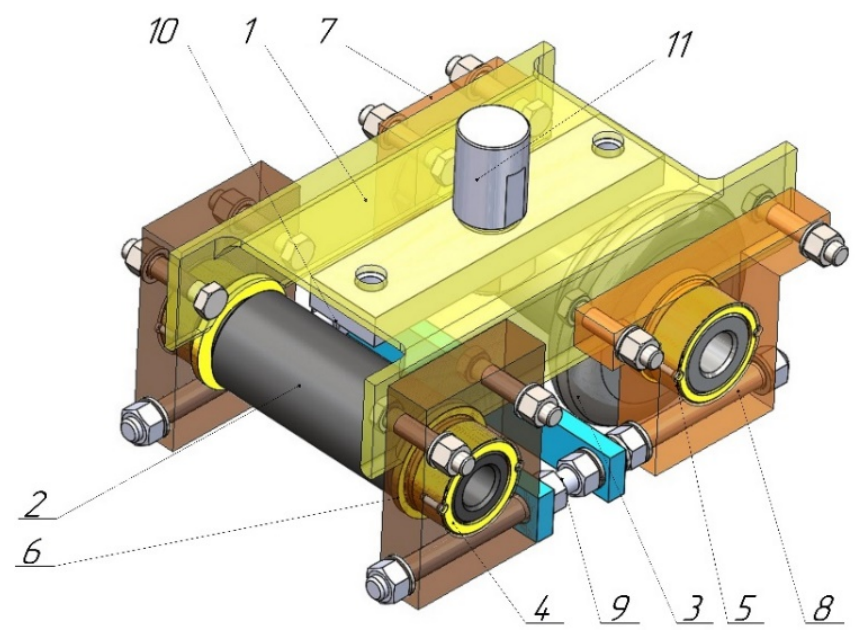

Fig. 2. Running head: 1 - channel; 2 - roll; 3 - shaft-wheel; 4, 5- bushings; 6, 7, 8 - housings; 9 - stud; 10 - holder, 11 - shank

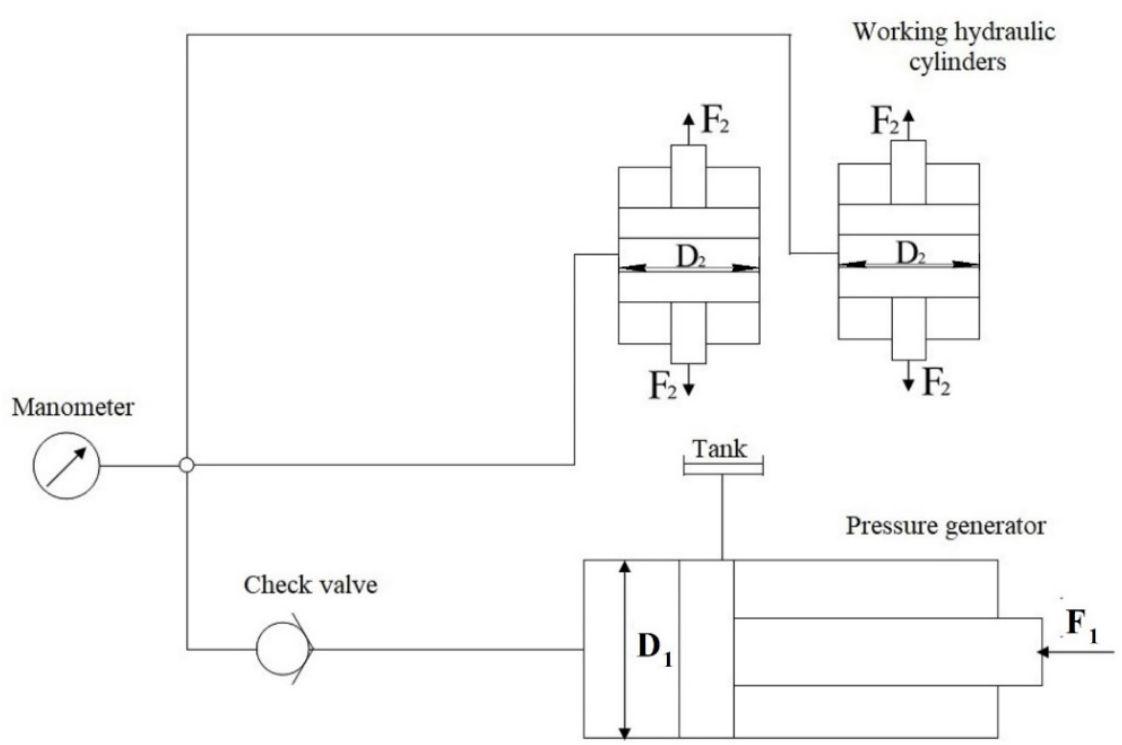

Fig. 3. The hydraulic system of the experimental setup 
Knowing the required force that must be generated by the piston, you can calculate the required pressure in the hydraulic system:

$$
p=F_{w}^{\text {setup }} / S_{p} \cdot n
$$

where $S_{p}$ is piston area; $\mathrm{n}$ is the number of hydraulic cylinders (the setup contains two hydraulic cylinders, $n=2$ ).

It is known that the weight of a loaded train car can be 70 tons [8]. The train car has four wheelsets. Then the load on one train wheel is be $F_{w}^{\text {train }}=70 \cdot 10^{3} \cdot 9.8 / 4 \cdot 2=85750 \mathrm{~N}$.

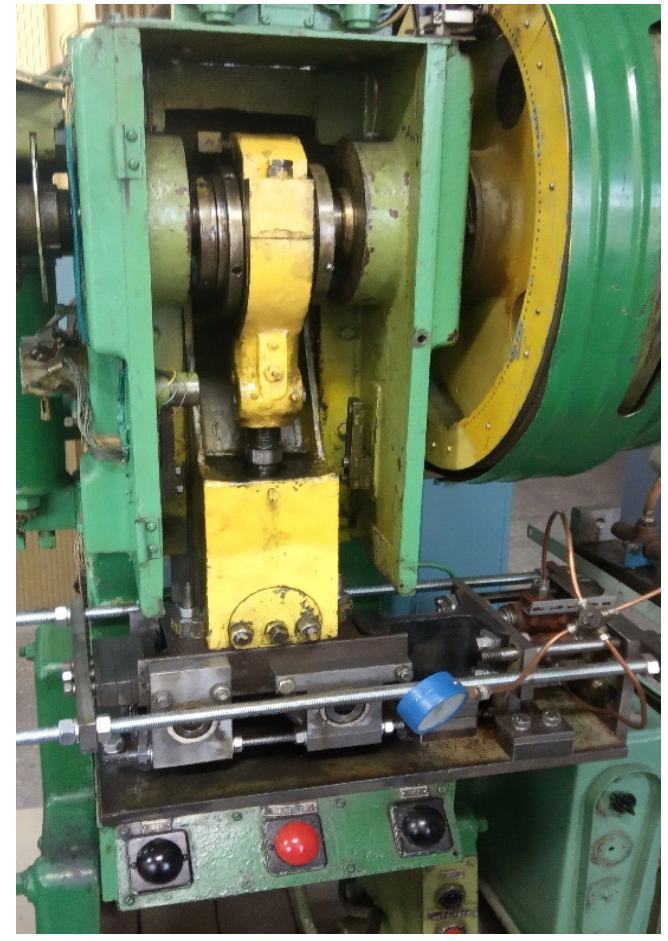

Fig. 4. General view of the experimental setup mounted on mechanical single-cylinder press of the K 2322 model with a nominal force of 16 tons

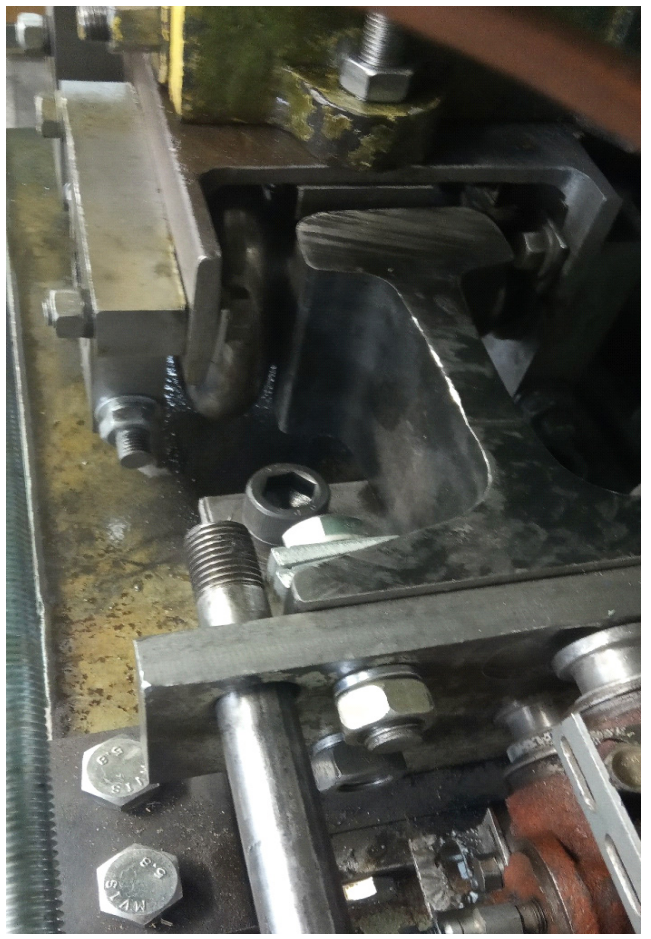

Fig. 5. General view of the friction unit "rail-wheel"

The radius of the train wheel in the center of the riding circle is $R_{w}=475 \mathrm{~mm}$. The radius of the shaft-wheel in the center of the riding circle of the setup is $R_{\text {setup }}=40 \mathrm{~mm}$. The radius of the rail head is $R_{\mathrm{r}}=500 \mathrm{~mm}$. Then coefficients are be: $m_{\text {train }}=0.395, m_{\text {setup }}=1.12$ [7]. Since mechanical properties of the wheel and rails are the same as parts (shaft-wheel and rail) in the setup then $E_{\text {eqv }}^{\text {train }}=E_{\text {eqv }}^{\text {setup }}$.

Using the formula (2), the force was calculated to be generated by the hydraulic system: $F_{w}^{\text {setup }}=3761.6 \mathrm{~N}$.

The pistons of the hydraulic cylinders have a diameter $D_{2}=35$ MM. Then to create needed force $F_{w}^{\text {setup }}$ the pressure in the hydraulic system must be: $p=1.95 \approx 2 \mathrm{M \Pi а}$.

The test program, which provides for two-hour tests, followed by defects (micro cracks) detecting on the rail body has been developed. Thus, studies are carried out for every 31920 load cycles. Research on the defects presence is carried out by fluorescent magnetic particle inspection method.

The fluorescent magnetic particle inspection method is based on the phenomenon of come together particles of magnetic powder under the influence of magnetic scattering fluxes arising over defects in magnetized objects that are tested [9]. The presence and length of indicator patterns caused by defect scattering fields are recorded visually or automatically by image processing devices. rail surface:

The following technological operations were applied during the fluorescent magnetic particle inspection of the

- $\quad$ surface preparation for inspection (degreasing with organic solvents);

- magnetization of the controlled object in two perpendicular directions by the applied field method (magnetization occurred simultaneously with the application of a luminescent suspension);

- inspection of the controlled surface when irradiated with ultraviolet rays with a wavelength of $360 \mathrm{~nm}$ and registration of indicator patterns of defects;

- $\quad$ assessment of inspection results. 
Before testing the rail in the setup (fig. 7), its surface was examined for cracks using the fluorescent magnetic particle inspection. In fig. 7 shows the image of the original rail during testing for the presence of cracks. As can be seen from fig. 7 , there are no cracks on the working surface of the rail. The image can be distinguished areas of the surface that deviate from the norm, but are not surface defects that affect the performance of the rail and do not reflect in UV light.

In Fig. 8, $a$ shows an image of the rail wear zone in UV light after 31920 load cycles. In Fig. 8, $b$ presents a photograph of the wear zone of the rail. There are no visible cracks on the surface of the rail.

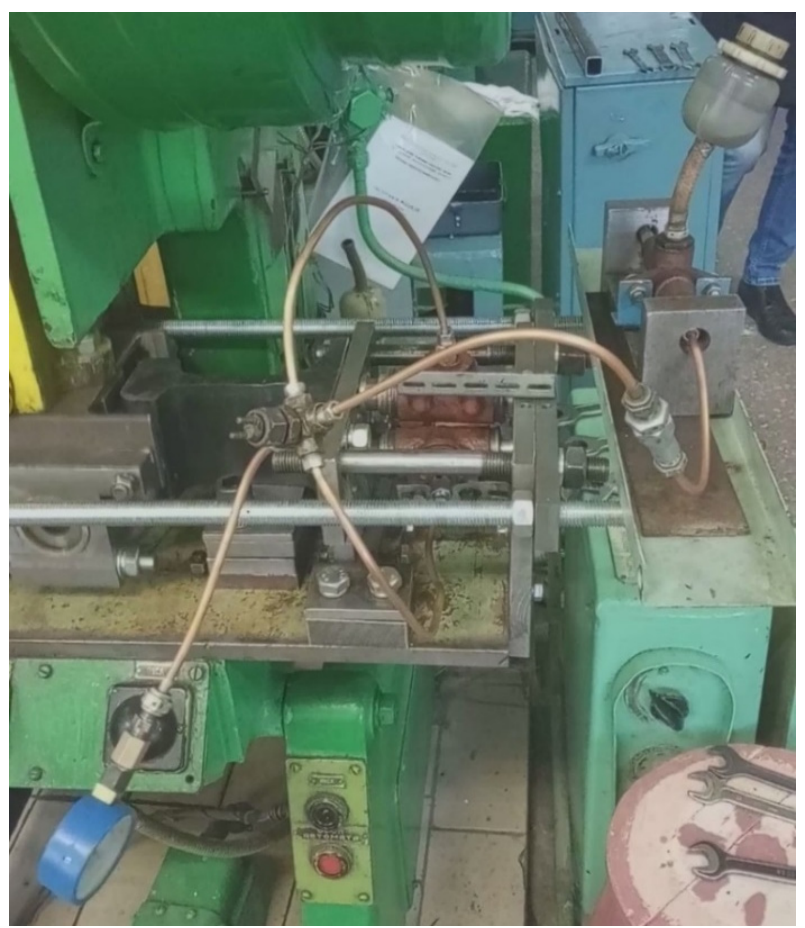

Fig. 6. General view of hydraulic system of the setup

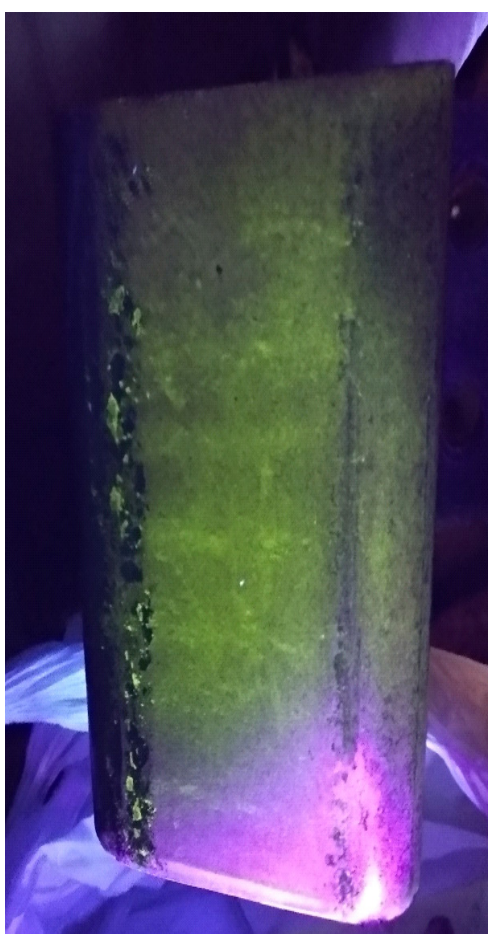

Fig. 7. Photo of the rail before testing

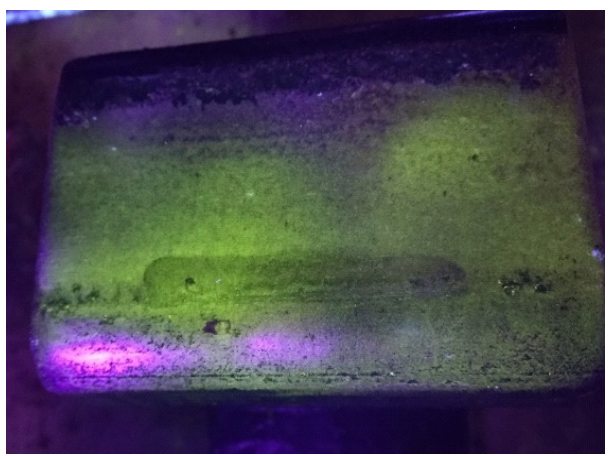

a

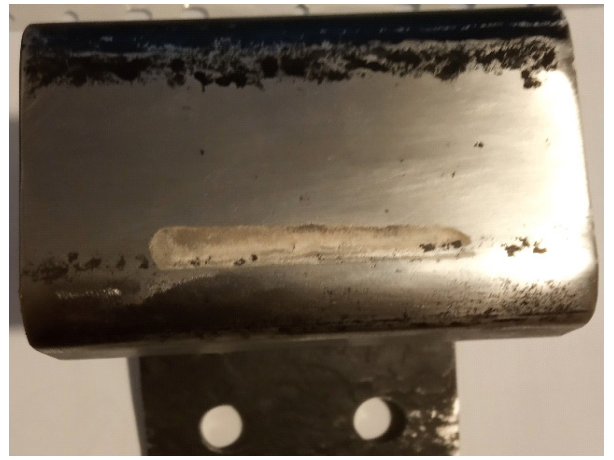

b

Fig. 8. Photos of the rail wear zone after 31920 load cycles: $a$ - image of the rail wear zone in UV light during flaw detection; $b$ - photograph of the rail wear zone 
A similar picture without cracks, as in Fig. 8 is shown in fig. 9 after 95760 load cycles.

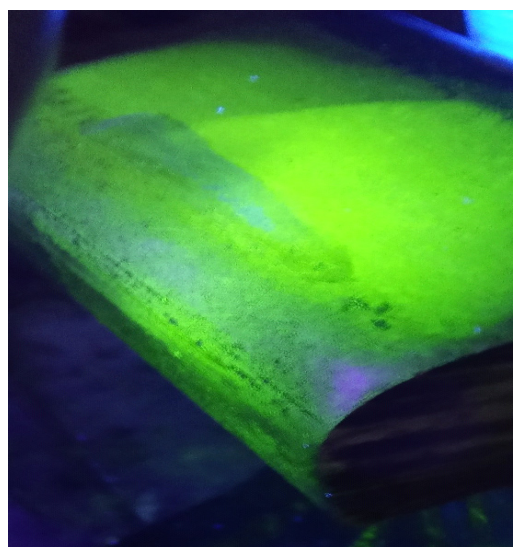

$a$

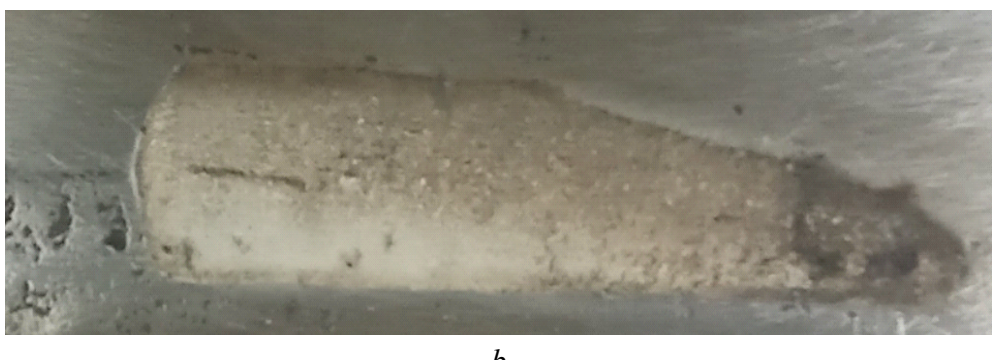

$b$

Fig. 9. Photos of the rail wear zone after 95760 load cycles: $a$ - image of the rail in UV light during flaw detection, $b$ - photograph of the rail wear zone

The crack initiation began after approximately 200-210 thousand load cycles. The first crack was fixed at 218120 load cycles (fig.10,a). Its length was $20 \mathrm{~mm}$. In fig. 10, $b$ shows the photograph of the wear surface of the rail after 255360 load cycles. Several cracks are clearly distinguished and tend to develop along the contact zone of the rail and shaft-wheel with indicated numbers of the load cycles (255360). This is broadly in line with the results presented in [10], which shows the occurrence of similar damage after 190-290 thousand load cycles, depending on the properties of rail steel (hardness, surface roughness, etc.).

The rough grinding $(R z=80 \mu \mathrm{m})$ can reduce the crack resistance of the rails by $70-80 \%$, which can be considered as a result of the influence of residual tensile stresses induced in the surface by strong local heating and increased roughness [10]. Under certain grinding conditions, the hardening formed during the grinding process to a certain extent neutralizes the effect of stress concentrators from the resulting microroughnesses, thereby increasing the crack resistance parameters. A decrease in roughness by $20 \mu \mathrm{m}$ allows one to increase the wear resistance by $20-25 \%$ due to an increase in compressive residual stresses and an increase in the microhardness of the surface layer [10]. hardness.

In papers [11-12] also confirms the influence of grinding modes on the wear resistance of rails and their surfaces

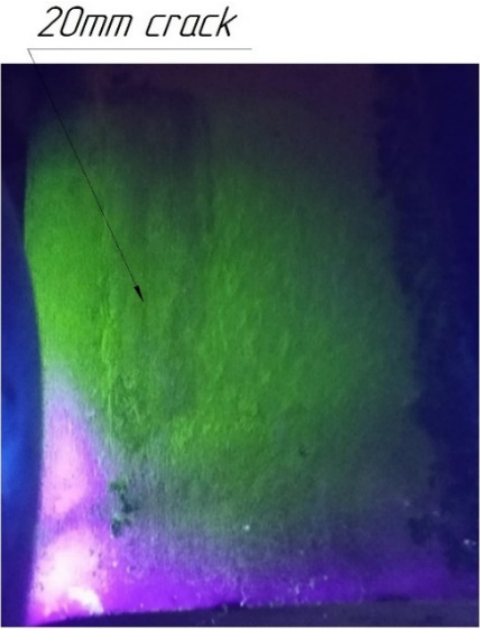

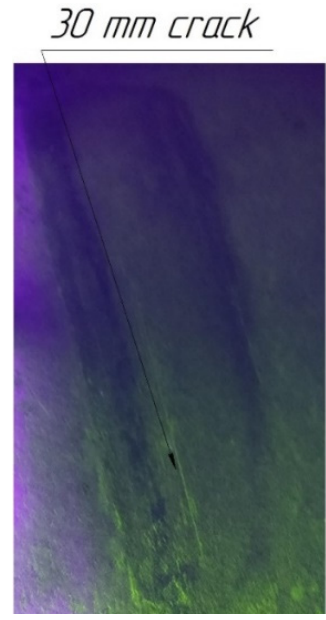

$b$

Fig. 10. Photos of rail wear zones with cracks: $a$ - after 218120 load cycles with $20 \mathrm{~mm}$ crack, $b$ - after 255360 load cycles with $30 \mathrm{~mm}$ crack

During the investigation of contact damage rail on the setup, in addition to detecting fatigue cracks and other surface defects, the shape and size of the wear zone were also determined. As can be seen from fig. 8, $b$ and fig. $9, b$, the shape of the worn zone of the rail is close to a rectangular trapezoid. This can be explained by the peculiarities of the experimental setup, when the force of pressing the rail to the wheel increased while the slider moves down. During the upward stroke, the pressing force decreased and its value was in the range of $3-5 \mathrm{kN}$. In the process of moving the slider, the pressure also varied in the hydraulic system from 1.5 to $3 \mathrm{MPa}$. The maximum pressure was in the lowest 
position of the slider. The relationship between the number of the load cycle with the worn area of the rail is presented as the graphical dependence in fig. 11.

Table 1 presents the results of studies, in particular, the geometric dimensions (length and width) of the wear zone, as well as the characteristics of defects that occur on the surface.

Table 1

\begin{tabular}{|c|c|c|c|}
\hline \multicolumn{4}{|c|}{ Research resuits } \\
\hline $\begin{array}{l}\text { Test time, } \\
\text { hours }\end{array}$ & $\begin{array}{l}\text { Number of } \\
\text { load cycles }\end{array}$ & $\begin{array}{c}\text { Maximum dimensions of } \\
\text { the wear zone (length and } \\
\text { width), mm }\end{array}$ & The presence and size of cracks, $\mathrm{mm}$ \\
\hline 0 & 0 & - & \multirow{7}{*}{ no cracks } \\
\hline 2 & 31920 & $45 \times 8$ & \\
\hline 4 & 63840 & $48 \times 9$ & \\
\hline 6 & 95760 & $50 \times 10$ & \\
\hline 8 & 127680 & $50 \times 12$ & \\
\hline 10 & 159600 & $52 \times 13$ & \\
\hline 12 & 191520 & $55 \times 15$ & \\
\hline $13 \mathrm{~h} 40 \mathrm{~min}$ & 218120 & $57 \times 15$ & $20 \mathrm{~mm}$ material discontinuity line \\
\hline 16 & 255360 & $58 \times 16$ & two longitudinal cracks longer than $30 \mathrm{~mm}$ \\
\hline 18 & 287280 & $60 \times 17$ & $\begin{array}{l}\text { the development of two longitudinal cracks almost } \\
\text { throughout the wear zone, the occurrence of two cracks } \\
\text { up to } 10 \mathrm{~mm} \text { long }\end{array}$ \\
\hline
\end{tabular}

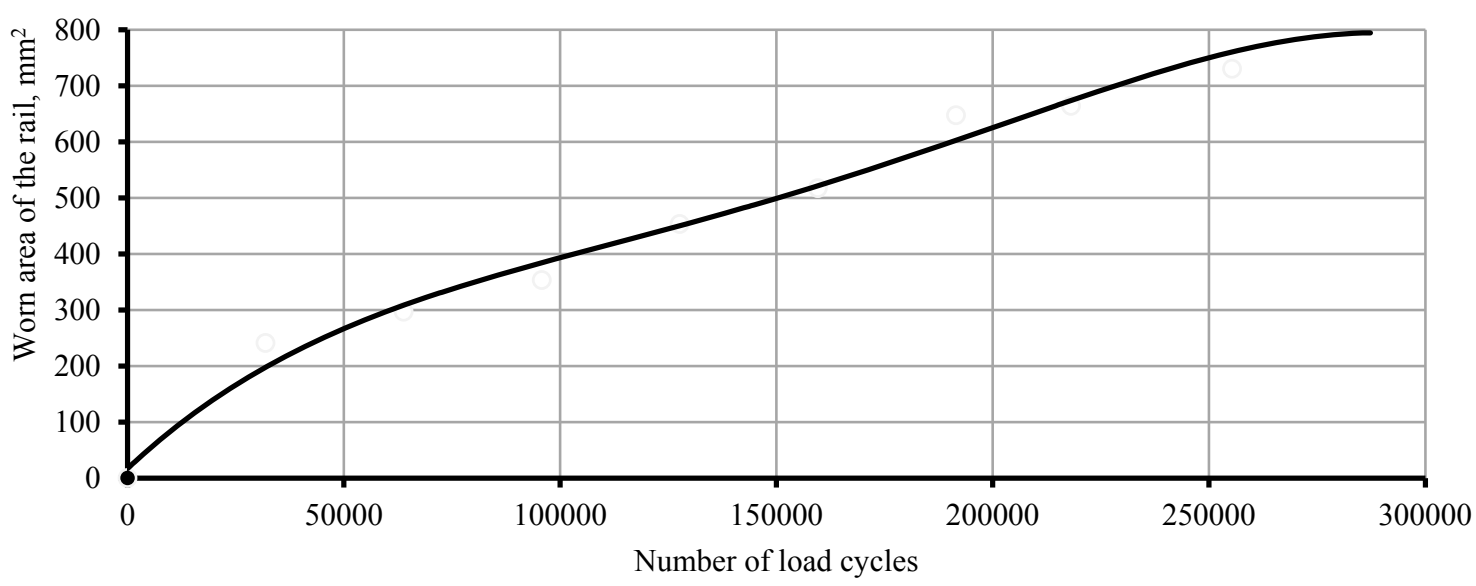

Fig. 11. The dependence of the number of load cycles on the worn area of the rail

As can be seen from table 1, the average crack growth rate is $0.0005 \mathrm{~mm} /$ load cycle after its occurrence. In addition, the number of cracks doubles approximately every 30 thousand load cycles since the first crack

General recommendations for the implementation of research of the railway rail for analysis of surface initiated rolling contact fatigue cracks

1. Fatigue research can be performed on a mechanical crank press with the use of specially designed setup. Each turn of the crank provides two cycles of loading on a rail. The calculation of the load on the rail to be created by the hydraulic system of the setup is calculated according to the dependence (2).

2. According to the results of the experiment, in order to more accurately record the moment of occurrence of the first crack on the rail surface, it is advisable to divide it into stages, each of which corresponds to 25 thousand load cycles.

3. After each load stage, it is recommended to use the fluorescent magnetic particle inspection method to detect cracks, which is highly sensitive and can detect surface microcracks with a width of $0.001 \mathrm{~mm}$ and a depth of $0.01 \mathrm{~mm}$.

\section{Conclusions}

1. To carry out experimental studies of the initiation and development of contact-fatigue defects on the surface of the rail in laboratory conditions, the test program was developed, the experimental setup was designed and manufactured. For the detection of defects of the surface of the rail was used the fluorescent magnetic particle 
inspection method. General recommendations are given for the study of the initiation and development of contactfatigue defects on the surface of the rail.

2. Experimental studies have shown that the occurrence of cracks on the rail surface is observed after 200-210 thousand load cycles, which generally coincides with previously known data.

3. With a further increase in the number of load cycles, the existing contact-fatigue cracks rapidly develop and new cracks form in the contact zone. After occurrence, the crack propagates at an average speed of $0.0005 \mathrm{~mm} / \mathrm{load}$ cycle. In addition, the number of cracks doubles approximately every 30 thousand load cycles since the first crack.

4. The worn area appears and increases on the surface of the rail during the wheel and rail come in contact. The worn area on the rail was already formed after the first test stage (31920 load cycles for 2 hours testing) with an area of about $241 \mathrm{~mm}^{2}$. The shape of the worn area of the rail is close to a rectangular trapezoid. This can be explained by the peculiarities of the experimental setup, when the force of pressing the rail to the wheel increased while the slider moves down. During the upward stroke, the pressing force decreased and its value was in the range of $3-5 \mathrm{kN}$. As the number of load cycles increased from 31920 to 287280, the worn area of the rail increased from 241 to $800 \mathrm{~mm}^{2}$.

\title{
Acknowledgements
}

All authors acknowledge the financial support provided by the Deutsche Forschungsgemeinschaft (DFG). The presented results are part of the DFG-project Uh 100/203-1.

\section{References}

1. Бйносов А.П. Методы повышения ресурса колесных пар тягового подвижного состава: Монография. - М.: ГОУ "Учебно-методический центр по образованию на железнодорожном транспорте", 2010. - 224 с.

2. Косарчук В.В. Прогнозирование долговечности рельсов по критерию возникновения трещин контактной усталости / В.В. Косарчук, А.В. Агарков // Збірник наукових праць ДЕТУТ. Серія “Транспортні системи і технології”. - 2012. Вип. 20. - С. 77-90.

3. Ekberg A. Fatigue of railway wheels and rails under rolling contact and thermal loading-an overview / A. Ekberg, E. Kabo // Wear. - 2005. - №366-367. - C. 1288-1300.

4. Tyfour W.R. Deterioration of rolling contact fatigue life of pearlitic rail steel due to dry-wet rolling-sliding line contact / W.R. Tyfour, J.H. Beynon, A. Kapoor // Wear. - 1996. - №197. - C. 255-265.

5. Воробьев А.А. Контактное взаимодействие колеса и рельса // Вестник ИрГТУ. Транспорт. - №3 (39). - 2009. C. $42-47$.

6. Дудкин Е.П. Прогнозирование формы и интенсивности износа колеса и рельса промышленных железных дорог / Е.П. Дудкин, М.В. Малахов, А.В. Башлыков // “Транспорт Российской Федерации”. Безопасность. - 2012. - № 3-4 (40-41). - С. 56-60

7. Підйомно-транспортні машини: Розрахунки підіймальних і транспортувальних машин: підручник для студентів вищих навчальних закладів, які навчаються за напрямом “Інженерна механіка" / В. С. Бондарєв, О. І. Дубинець, М. П. Колісник та ін. - Київ: Вища школа, 2009. - 734 с.

8. Подвижной состав железных дорог. В 2 ч. Ч. 1 Грузовые вагоны: учебно-методическое пособие / Е.А. Довгаль, Е.А. Копотун, Б.Е. Копотун, Т.В. Наноян / под ред. А.Е. Довгаля; ФГБОУ РГУПС. - Ростов н/Д, 2012. - 96 с.

9. ГОСТ 21105-87 Контроль неразрушающий.Магнитопорошковый метод. - [Чинний від 1988-01-01]. - М.: ИПК Издательство стандартов, 1988. - 13 с. - (Межгосударственный стандарт).

10. Матафонов В.А. Технологическое обеспечение качества поверхности рельсов при шлифовании в условиях железнодорожного пути/ А.В. Матафонов, А.Н. Пыко, А.С. Ильиных // Вестник ЮУрГУ. Серия "Машиностроение”. 2015. - т. 15. - № 1. - C. 80-92.

11. Uhlmann E. Influence of railway-track grinding on the track material condition and tribological behaviour / E. Uhlmann, M. Bobyr, Y. Borodiy, P. Lypovka, J. Thalau, P. Protsenko // Advanced Materials Letters. - 2019. - №10(7). - C $449-454$.

12. Bobyr. M. The wear resistance research of the rail contact surface depending on the grinding process / M. Bobyr, Y. Borodii, P. Protsenko, E. Uhlmann, J. Thalau, P. Lypovka // Mechanics and Advanced Technologies. - 2019. - №2. - C. 14-22.

\section{Исследование рельсов железнодорожных путей на контактную повреждаемость}

\author{
Ю. П. Бородий, П. Ю. Проценко, А. И. Пэтрышын, Э. Ульман, Я. Талау, П. Липовка, В. Н. Горбык, \\ В. Ю. Глуховский
}

Проблематика. Под влиянием динамической нагрузки от поездов и природных условий, железная дорога повреждается, что характеризуется появлением дефектов и остаточных деформаций железнодорожного пути, которые ведут к ускоренному износу и выходу из строя других элементов рельсошпальной решетки. Появление указанных дефектов, отказов и разрушений элементов рельсошпальной решетки связано с действием дополнительных локальных напряжений, возникающих в рельсах железнодорожного пути. На некачественной рельсошпальной решетке с отклонениями 
параметров рельсовой колеи, при движении поезда, возникает нерасчетное взаимодействие пути и подвижного состава с локальной перегрузкой элементов взаимодействия по длине пути. Как правило, нерасчётное взаимодействие пути и подвижного состава сопровождается ударным воздействием колеса и рельса с перегрузкой пятна контакта. При ударном взаимодействия колеса и рельса в головке рельса возникают напряжения, превышающие предел выносливости. При этом в головке рельса зарождаются и начинают развиваться дефекть контактно-усталостного происхождения в виде горизонтальных вертикальных и поперечных трещин.

Цель исследования. Осуществление практических исследований зарождения и развития трещин контактно-усталостного происхождения путем износа рельсов в лабораторных условиях.

Методика реализации. Для исследования рельсов на контактную повреждаемость была спроектирована и изготовлена экспериментальная установка. Установка установлена на механический однокривошипный пресс модели К 2322 номинальным усилием 16 тс. при номинальной частоте ходов - 120 в минуту. Основная часть экспериментальной установки содержит узел трения "колесо-рельс". Силу прижима рельса к колесу обеспечивает гидравлическая система. Для проведения исследований была разработана программа испьтаний, которая предусматривает двухчасовье испытания, после которых проводятся исследования на наличие дефектов (микротрешин) на рельсе. Исследования на наличие дефектов проводятся методом магнитопорошкового неразрушаюшего контроля.

Результаты исследования. После проведенных исследований установлено, что возникновение контактно-усталостных трещин в головке рельса состоялось примерно после 200000 циклов нагрузок. Это в целом совпадает с результатами, представленными в других работах, в которых отмечается возникновение подобных повреждений после $190-290$ тысяч циклов, в зависимости от свойств рельсовой стали (твердости, шероховатости поверхности и т.п.).

ВыводыГлавной причиной зарождения и развития контактно-усталостных дефектов в головке рельса является недостаточная контактно-усталостная прочность рельсовой стали. Для проведения практических исследований в лабораторных условиях была разработана методика, сконструирована и изготовлена экспериментальная установка. Экспериментальными исследованиями установлено, что возникновение дефектов на поверхности рельса наблюдается после 200-210 тысяч цииклв нагрузок. При дальнейшем увеличении числа циклов нагрузок происходит быстрое развитие существуюших контактно-усталостных трещчин и образование новых трещчин в зоне контакта.

Ключевые слова: рельсы и колеса железнодорожного транспорта, износ рельсов железнодорожного пути, контактная повреждаемость, дефекты рельсов, контактно-усталостные трещины, магнитопорошковый метод неразрушающего контроля.

\title{
Дослідження рейок залізничної колії на контактну пошкоджуваність
}

\author{
Ю. П. Бородій, П. Ю. Проценко, А. І. Петришин, Е. Ульман, Я. Талау, П. Липовка, В. М. Горбик, В. Ю. Глуховський
}

Проблематика. Під впливом динамічного навантаження від поїздів та природних умов, залізнична колія пошкоджується, що характеризується появою дефектів та залишкових деформачій залізничного шляху, які ведуть до прискореного зношування і виходу з ладу інших елементів рейкошпальної решітки. Поява вказаних дефектів, відмов і руйнувань елементів рейкошпальної решітки пов'язана з дією додаткових локальних напружень, щяо виникають в рейках залізничної колії. На неякісній рейкошпальній решітиі з відхиленнями параметрів рейкової колії, при русі поӥзда, виникає нерозрахована взаємодія колії та рухомого складу з локальним перевантаженням елементів взаємодії по довжині шляху. Як правило, нерозрахована взаємодія колії та рухомого складу супроводжується ударним впливом колеса і рейки з перевантаженням зони контакту. При ударній взаємодії колеса і рейки в головиі рейки виникають напруження, щяо перевищують межу витривалості. При цьому в головиі рейки зароджуються $і$ починають розвиватися дефекти контактно-втомного походження у вигляді горизонтальних вертикальних та поперечних тріщин.

Мета дослідження. Здійснення практичних досліджень зародження та розвитку тріщин контактно-втомного походження шляхом зношування рейок в лабораторних умовах.

Методика реалізації. Для дослідження рейок на контактну пошкоджуваність була спроектована та виготовлена експериментальна установка. Установка встановлена на механічний однокривошипний прес моделі К 2322 номінальним зусиллям 16 тс. при номінальній частоті ходів - 120 за хвилину. Основна частина експериментальної установки містить вузол тертя "колесо-рейка". Силу притискування рейки до колеса забезпечує гідравлічна система. Для проведення досліджень була розроблена програма випробувань, яка передбачає двогодинні випробування, після яких проводяться дослідження на наявність дефектів (мікротріщиин) на рейці. Дослідження на наявність дефектів проводяться методом магнітопорошкового неруйнівного контролю.

Результати дослідження. Після проведених досліджень встановлено, щзо виникнення контактно-втомних тріщин 8 головиі рейки відбулось приблизно після 200 тисяч ицклів навантажень. Це в иілому збігається з результатами, представленими в інших роботах, в яких відмічається виникнення подібних пошкоджень після 190-290 тисяч ииклів, залежно від властивостей рейкової сталі (твердості, шорсткості поверхні тощо).

Висновки. Головною причиною зародження $і$ розвитку контактно-втомних дефектів в головиі рейки $\epsilon$ недостатня контактно-втомна міџність рейкової сталі. Для проведення практичних досліджень в лабораторних умовах була розроблена методика, сконструйована та виготовлена експериментальна установка. Експериментальними дослідженнями встановлено, щь виникнення дефектів на поверхні рейки спостерігається після 200-210 тисяч циклів навантажень. При подальшому збільшенні числа ииклів навантажень відбувається швидкий розвиток існуючих контактно-втомних тріщин та утворення нових тріщин в зоні контакту.

Ключові слова: рейки та колеса залізничного транспорту, зношування рейок залізничної колії, контактна пошкоджуваність, дефекти рейок, контактно-втомні тріщини, магнітопорошковий метод неруйнівного контролю. 


\section{References}

1. Buinosov, A.P. (2010), Metody povysheniya resursa kolesnykh par tyagovogo podvizhnogo sostava [Handbook of probability theory and mathematical statistics], GOU "Uchebno-metodicheskiy tsentr po obrazovaniyu na zheleznodorozhnom transporte", Moscow, Russia.

2. Kosarchuk, V.V., Aharkov, A.V. (2012), "Prediction of rail durability by the criterion for the occurrence of contact fatigue cracks", Zbirnyk naukovykh prats DETUT, Seriia "Transportni systemy i tekhnolohii", vol. 20, pp. 77-90.

3. Ekberg, A. and Kabo, E. (2005), "Fatigue of railway wheels and rails under rolling contact and thermal loading-an overview", Wear, vol. 366-367, pp. 1288-1300.

4. Tyfour, W.R., Beynon, J.H. and Kapoor, A. (1996), "Deterioration of rolling contact fatigue life of pearlitic rail steel due to dry-wet rolling-sliding line contact", Wear, vol. 197, pp. 255-265.

5. Vorobev, A.A. (2009), "Contact interaction of a wheel and a rail", Vestnik IrGTU. Transport, vol. 3, no. 39, pp. $42-47$.

6. Dudkyn, E.P., Malakhov, M.V. and Bashlykov, A.V. (2012), "Prediction of the shape and intensity of wear of the wheel and rail of industrial railways", "Transport Rossiyskoy Federatsii”. Bezopasnost, vol. 3-4 (40-41), pp. 56-60.

7. Bondariev, V.S., Dubynets, O.I., Kolisnyk, M.P., Bondariev, S.V., Horbatenko, Y.P. and Barabanov, V.Y. (2009), Pidiomnotransportni mashyny: Rozrakhunky pidiimalnykh i transportuvalnykh mashyn: pidruchnyk dlia studentiv vyshchykh navchalnykh zakladiv, yaki navchaiutsia za napriamom "Inzhenerna mekhanika" [Carrying and lifting machines machines: Calculations of carrying and lifting machines: the textbook for students of higher educational institutions studying in the direction "Engineering Mechanics"], Vyshcha shkola, Kyiv, Ukraine.

8. Dovhal, E.A., Kopotun, E.A., Kopotun, B.E. and Nanoian, T.V. (2012), Podvizhnoi sostav zheleznykh dorog, vol. 2, no. 1, Gruzovye vagony: uchebno-metodicheskoe posobie [Rolling stock of railways. In two parts. Part 1. Freight wagons: the methods handbook], in Dovhal, A.E. (ed.), Rostov State Transport University, Rostov on Don, Russia.

9. Interstate standard, (1988), GOST 21105-87, Kontrol nerazrushayushchiy. Magnitoporoshkovyy metod [Nondestructive testing. Method of magnetic particle testing], STANDARTINFORM, Moscow, Russia.

10. Matafonov, A.V., Pyiko, A.N. and Ilinyih, A.S., (2015), "Tehnologicheskoe obespechenie kachestva poverhnosti relsov pri shlifovanii v usloviyah zheleznodorozhnogo puti" [Technological support for the quality of the surface of rails during grinding in a railway], Vestnik YuUrGU. Seriya "Mashinostroenie", vol. 15, no. 1, pp. 80-92.

11. Uhlmann, E., Bobyr, M., Borodiy, Y., Lypovka, P., Thalau, J. and Protsenko, P. (2019), "Influence of railway-track grinding on the track material condition and tribological behavior", Advanced Materials Letters, vol. 10, no. 7, pp. 449-454. https://doi.org/10.5185/amlett.2019.2234

12. Bobyr, M., Borodii, Y., Protsenko, P., Uhlmann, E., Thalau, J. and Lypovka, J. (2019), "The wear resistance research of the rail contact surface depending on the grinding process", Mechanics and Advanced Technologies, vol. 86, no. 2, pp. 14-22. https://doi.org/10.20535/2521-1943.2019.86.181036 